Division of Geological \& Geophysical Surveys

\title{
MAJOR-OXIDE AND TRACE-ELEMENT GEOCHEMICAL DATA FROM ROCKS COLLECTED IN THE RICHARDSON MINING DISTRICT, BIG DELTA QUADRANGLE, ALASKA
}

Evan Twelker, Alicja Wypych, Karri R. Sicard, Travis J. Naibert,

Melanie B. Werdon, Jennifer E. Athey, Amanda L. Willingham, and Alec C. Lockett

Raw Data File 2017-11

$\$ 1.00$

This report has not been reviewed for technical content or for conformity to the editorial standards of DGGS

November 2017

STATE OF ALASKA

DEPARTMENT OF NATURAL RESOURCES

DIVISION OF GEOLOGICAL \& GEOPHYSICAL SURVEYS 
STATE OF ALASKA

Bill Walker, Governor

DEPARTMENT OF NATURAL RESOURCES

Andrew T. Mack, Commissioner

DIVISION OF GEOLOGICAL \& GEOPHYSICAL SURVEYS

Steve S. Masterman, State Geologist \& Director

Publications produced by the Division of Geological \& Geophysical Surveys are available for download from the DGGS website (dggs.alaska.gov). Publications on hard-copy or digital media can be examined or purchased in the Fairbanks office:

Alaska Division of Geological \& Geophysical Surveys (DGGS)

3354 College Road | Fairbanks, Alaska 99709-3707

Phone: 907.451.5010 | Fax 907.451.5050

dggspubs@alaska.gov $\mid$ dggs.alaska.gov

DGGS publications are also available at:

Alaska State Library, Historical

Collections \& Talking Book Center

395 Whittier Street

Juneau, Alaska 99801

Alaska Resource Library and

Information Services (ARLIS)

3150 C Street, Suite 100

Anchorage, Alaska 99503

\section{Suggested citation:}

Twelker, Evan, Wypych, Alicja, Sicard, K.R., Naibert, T.J., Werdon, M.B., Athey, J.E., Willingham, A.L., and Lockett, A.C., 2017, Major-oxide and trace-element geochemical data from rocks collected in the Richardson mining district, Big Delta Quadrangle, Alaska: Alaska Division of Geological \& Geophysical Surveys Raw Data File 2017-11, 4 p. http://doi.org/10.14509/29779
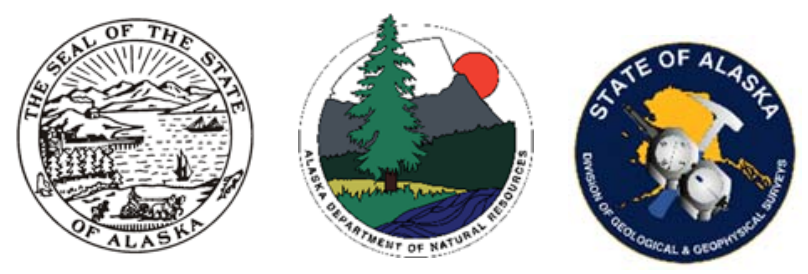


\title{
MAJOR-OXIDE AND TRACE-ELEMENT GEOCHEMICAL DATA FROM ROCKS COLLECTED IN THE RICHARDSON MINING DISTRICT, BIG DELTA QUADRANGLE, ALASKA
}

\author{
Evan Twelker ${ }^{1}$, Alicja Wypych², Karri R. Sicard ${ }^{2}$, Travis J. Naibert' ${ }^{2}$, \\ Melanie B. Werdon², Jennifer E. Athey ${ }^{2}$, Amanda L. Willingham², and Alec C. Lockett ${ }^{3}$
}

\section{INTRODUCTION}

During the 2017 field season, geologists from the Alaska Division of Geological \& Geophysical Surveys (DGGS) conducted geologic mapping and sampling of part of the Richardson Mining District southeast of Fairbanks, including parts of the Big Delta B-4, B-5, and C-5 quadrangles. The project area is about 30 miles west of the Pogo gold mine and covers the currently active Montecristo and Uncle Sam gold-exploration properties. The goal of DGGS's work in this area is to conduct a mineral-resource assessment and to build an improved understanding of the area's geology and controls on gold mineralization to facilitate industry exploration targeting.

This report is based on 17 days of fieldwork completed June 23-July 3, July 18-20, and August 11-13, 2017 by two to seven DGGS geologists. The study area is bound by the Pogo Road to the southeast and the Trans-Alaska Pipeline access road to the southwest (fig. 1); the crew accessed the interior of the study area by helicopter, allterrain vehicles, and foot. The Richardson area is characterized by moderate-relief hills and boreal spruce and deciduous forest typical of interior Alaska. Loess deposits of variable thickness blanket the area, and deposits of forest-covered eolian sand, including well-formed dune fields, cover the southeastern quadrant of the area along Shaw Creek. Rock outcrop accounts for much less than one percent of the study area, consequently, the majority of rock samples were collected from pits, up to 1-meter-deep, dug with shovels into rocky colluvial deposits below the surficial loess or sand.

Highlights of geochemical results include 2.67 parts per million ( $\mathrm{ppm}$ ) gold and $68.4 \mathrm{ppm}$ silver from a float sample collected at the Naosi prospect. An in-place, surface rock sample collected from the Mon prospect area assayed $2.42 \mathrm{ppm}$ gold and $23 \mathrm{ppm}$ silver. Both prospects are part of the Montecristo property. Whole-rock analyses indicate the granitic dikes that are abundant on the Montecristo and Uncle Sam properties are peraluminous granites of arc character. They most closely resemble the Early Cretaceous peraluminous felsic dikes documented in the southeastern Richardson district by Graham (2002); they are less similar (less peraluminous) to the ca. 90 Ma Gold Run intrusion (Graham, 2002) and Birch Lake pluton (Burns and others, 1993).

Amphibolite samples are basaltic in composition and have island-arc tholeiite or mid-ocean ridge basalt character, similar to unit MzPza amphibolites in the Salcha River-Pogo area (Werdon and others, 2004).

\footnotetext{
${ }^{1}$ Alaska Division of Geological \& Geophysical Surveys, 3354 College Road, Fairbanks, Alaska 99709-3707; evan.twelker@alaska.gov

${ }^{2}$ Alaska Division of Geological \& Geophysical Surveys, 3354 College Road, Fairbanks, Alaska 99709-3707

${ }^{3}$ Colorado College, Department of Geology, 14 East Cache la Poudre St., Colorado Springs, CO, 80903
} 
The analytical data tables associated with this report are available in digital format as comma-separated value (CSV) files. Additional details about the organization of information are noted in the accompanying metadata file. All files can be downloaded from the DGGS website (http://doi.org/10.14509/29779).

Samples collected during this project, as well as laboratory sample rejects and pulps, will be stored at DGGS for the duration of the project and will be available for public viewing upon request. Once the project concludes, the samples and pulps will be stored at the Alaska Geological Materials Center in Anchorage.

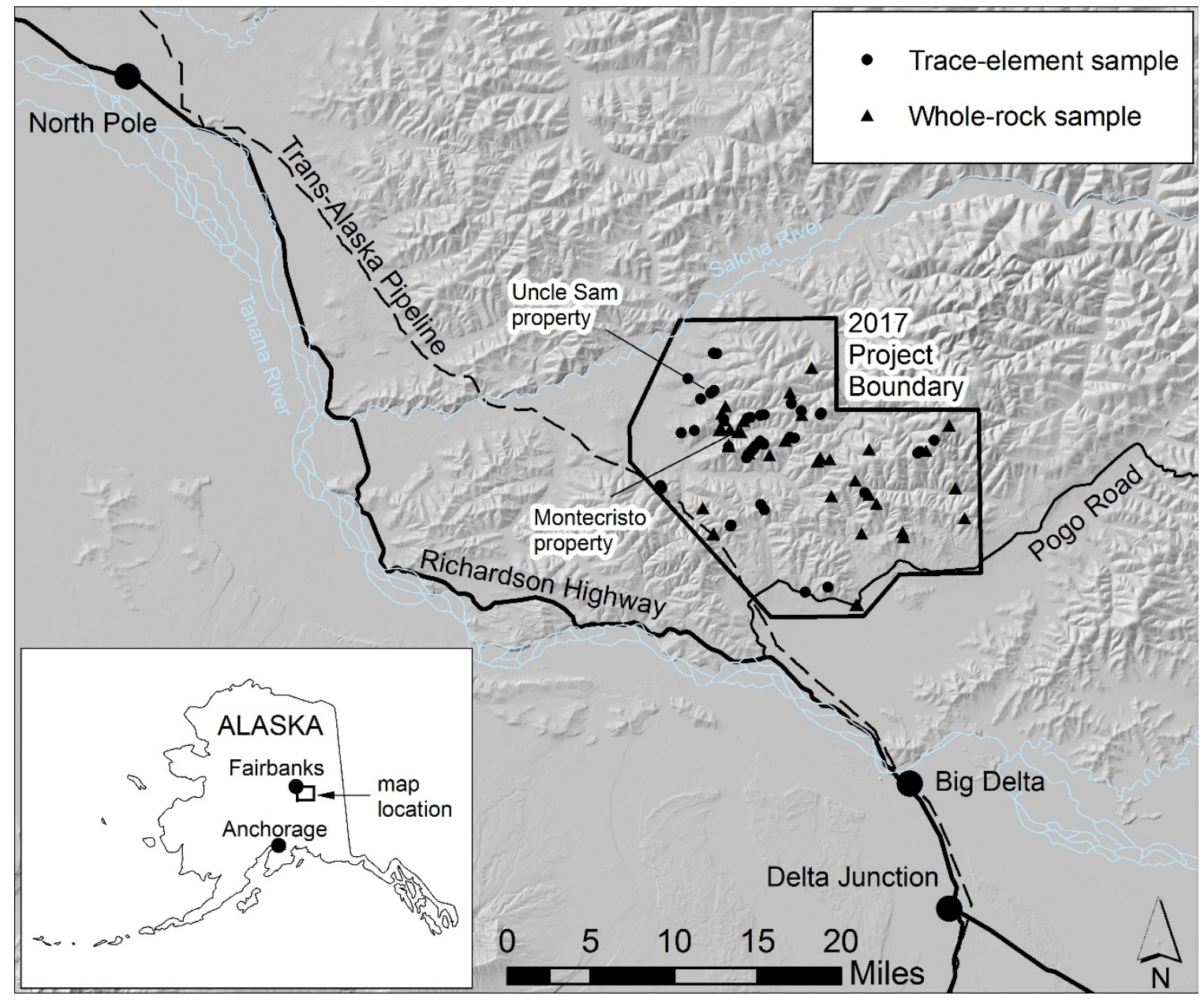

Figure 1. Location map showing the 2017 Richardson project area and sample locations.

\section{DOCUMENTATION OF METHODS}

\section{Sample Collection}

Rock samples were collected for two different purposes. First, samples of visibly mineralized or altered rock were preferentially collected and analyzed for trace-element geochemistry. Second, igneous and metaigneous rocks showing little alteration or weathering were collected for whole-rock major-oxide, minor-oxide, and traceelement analyses to aid in classification and study of petrogenesis and tectonic setting. Most samples are 'grab' samples, which were collected for their overall representation of the outcrop. However, a few samples are 'select' samples, which were more deliberately collected from a specific feature, as noted in the sample field description. 
Location data were collected using Trimble Juno T41/5 WAAS-enabled GPS devices running ArcGIS for Windows Mobile. Data were merged into an ArcGIS geodatabase. WAAS-enabled GPS devices have a reported error of about $1 \mathrm{~m}$. Latitude and longitude are reported in the WGS84 datum.

Magnetic susceptibility measurements were collected using Terraplus KT 5-, 6-, 9-, and 10-model handheld magnetic susceptibility meters. The values reported herein are for average Système International (SI) measurements performed on representative surfaces of the sampled rock outcrop.

\section{Sample Preparation}

Rock samples were processed by ALS Geochemistry using their PREP-31 package. The samples were crushed to greater than 70 percent passing through a $2 \mathrm{~mm}$ mesh, and a 250-g split was pulverized to greater than 85 percent of the material being less than 75 microns in diameter. Prior to crushing, samples for whole-rock analysis were trimmed by DGGS staff to remove weathering, and cut surfaces were sanded to remove any saw metal.

\section{Analytical Methods}

Samples were analyzed for a variety of suites of major and trace elements depending on the sample type. In addition to ALS Geochemistry' accredited (ISO/IEC 17025-2005) internal quality-control program, DGGS monitored analysis quality with one standard reference material per batch of 20 analyses.

Major- and trace-element values for rock samples were determined by ALS Geochemistry method ME-MS61: Fouracid digestion followed by inductively-coupled plasma-atomic emission spectrometry (ICP-AES) and inductively-coupled plasma-mass spectroscopy (ICP-MS); Au values were analyzed using flux digestion and fire assay and ICP-AES (ALS Geochemistry method Au-ICP21).

Samples that exceeded detection limits for elements of interest were reanalyzed using specific elemental tests. Overlimit values for As were analyzed using four-acid digestion followed by inductively-coupled plasma-atomic emission spectrometry (ALS Geochemistry method ME-OG62).

For whole-rock geochemistry samples, major and minor oxides were analyzed by lithium metaborate fusion digestion and ICP-AES (ALS Geochemistry method ME-ICP06). Trace elements, including rare-earth elements, were determined using lithium metaborate fusion digestion and ICP-MS (ALS Geochemistry method MEMS81). Ag, Cd, Co, Cu, Li, Mo, Ni, Pb, Sc, and $\mathrm{Zn}$ were determined by four-acid digestion and ICP-AES (ALS Geochemistry method ME-4ACD81); and $\mathrm{As}, \mathrm{Bi}, \mathrm{Hg}$, In, Re, Sb, Se, Te, and $\mathrm{Tl}$ were determined by aqua regia digestion followed by ICP-MS (ALS Geochemistry method ME-MS42). Total C and S were analyzed by Leco furnace (ALS Geochemistry methods C-IR07 and S-IR08, respectively). Pt, Pd, and Au were analyzed by lead oxide fire assay with ICP-MS finish (ALS Geochemistry method PGM-MS23). Where only Au values are reported, samples were analyzed using flux digestion and fire assay and ICP-AES (ALS Geochemistry method $\mathrm{Au}-\mathrm{ICP} 21)$.

For each sample, data tables contain either assay values or coded-value placeholders (null = not analyzed; $-1=$ the element's assay result is less than the lower detection limit for the method; -2 = the element's assay result is greater 
than the upper detection limit for the method). Detection limits for each of the reported elemental values obtained by the various methods are documented in the metadata file.

\section{ACKNOWLEDGMENTS}

The DGGS Richardson geologic mapping project was funded by the State of Alaska.

\section{REFERENCES}

Burns, L.E., Solie, D.N., and Newberry, R.J., 1993, Digital files of geochemical analyses of plutonic rocks in eastcentral interior Alaska: Alaska Division of Geological \& Geophysical Surveys Public Data File 93-44, 58 p. http://doi.org/10.14509/1603

Graham, G.E., 2002, Geology and gold mineralization of the Richardson district, east-central Alaska: Fairbanks, Alaska, University of Alaska Fairbanks, M.S. thesis, 150 p.

Werdon, M.B., Newberry, R.J., Athey, J.E., and Szumigala, D.J., 2004, Bedrock geologic map of the Salcha RiverPogo area, Big Delta Quadrangle, Alaska: Alaska Division of Geological \& Geophysical Surveys Report of Investigation 2004-1B, 19 p., 1 sheet, scale 1:63,360. http://doi.org/10.14509/3209 